\title{
Competitividade e barreiras comerciais a produção de frango brasileira na perspectiva dos gestores: uma avaliação usando a Matriz de Impactos Cruzados - MIC MAC
}

\section{Competitiveness and commercial barriers to Brazilian chicken production from the perspective of managers: An evaluation using the Cross Impacts Matrix - MIC MAC}

\author{
Arceste Leite Filho ${ }^{1}$ \\ Mirian Beatriz Schneider ${ }^{2}$
}

\section{RESUMO}

Este trabalho se propôs analisar as barreiras tarifárias e não tarifárias sobre o comércio internacional de carne de frango, e seu impacto sobre a comercialização mundial entre os anos 2015 e 2016, com base em entrevistas realizadas com gestores das principais indústrias produtoras de carne de frango da região oeste do Paraná. Para análise dos fatores que influenciam nas exportações, foi utilizado o Método MICMAC que apontou variáveis internas como legislação complexa, burocracia interna e carga tributária, consideradas entraves às exportações brasileiras. O método mostrou ainda as variáveis externas que podem afetar a competitividade da produção de frango como barreiras sanitárias, técnicas e tarifárias, além de legislação específica. O sistema MICMAC, apesar de ser uma ferramenta de análise de dados, não é capaz de descartar dados irrelevantes, ou perceber que este ou aquele não se enquadra bem no contexto a ser analisado.

\section{Palavras-chave: Frango, Exportações, Barreiras}

\section{ABSTRACT}

The objective of this study was to analyze tariff and non-tariff barriers on international trade in chicken meat and its impact on world trade between the years 2015 and 2016, based on interviews with managers of the main chicken meat producing western region of Paraná. In order to analyze the factors influencing exports, the MICMAC Method was used which pointed to internal variables such as complex legislation, internal bureaucracy and tax burden, which are considered barriers to Brazilian exports. The method also showed the external variables that can affect the competitiveness of chicken production as sanitary, technical and tariff barriers, as well as specific legislation. The MICMAC system, despite being a data analysis tool, is not able to discard irrelevant data, or to realize that this or that one does not fit well in the context to be analyzed.

Key words: Chicken, Exports, Barriers

JEL: F1, Q1.

\section{INTRODUÇÃO}

\footnotetext{
${ }^{1}$ Mestre em Desenvolvimento Regional e Agronegócios, MBA em Gestão de Comércio Exterior e Negócios Internacionais (FGV, 2015), graduação em Medicina Veterinária pela Universidade da Região da Campanha (1990).. E-mail: arceste@lar.ind.br

${ }^{2}$ Economista. Prof Associada do Colegiado de Ciências Econômicas e do Programa de Pós Graduação em Desenvolvimento Regional e Agronegócio da Unioeste. Pos-Doc em Economia pela USP/ESALQ e Dra em História Econômica pela UNILEÓN/ES. E-mail : mirian-braun@hotmail.com.
} 
Sob a ótica da competitividade, o comércio internacional é influenciado pela tecnologia disponível, preços, custos dos fatores, taxas de câmbio, taxas de paridade entre os parceiros comerciais, custos de transporte, estrutura de incentivos, barreiras tarifárias e não tarifárias, entre outros fatores (PAULA et al., 2007). Segundo SECEX (2016), as barreiras ao comércio internacional podem ser classificadas, segundo sua natureza, em tarifárias (tarifas de importação, outras taxas e valoração aduaneira), não-tarifárias (restrições quantitativas, licenciamento de importações, procedimentos alfandegários, medidas antidumping e compensatórias) e técnicas (normas e, ou, regulamentos técnicos e fitossanitários).

Com relação à avicultura, pode-se afirmar que com a integração econômica e abertura de novos mercados, houve intensa modernização do segmento, que se tornou mais competitivo não só em razão da concorrência entre países, como também com as demais fontes de proteína existentes. Eficiência econômica, controle sanitário e produtividade são pré-requisitos de sobrevivência nesse mercado cada vez mais exigente. Neste setor, impor barreiras ao comércio internacional implica redução de competitividade e lucratividade. O segmento enfrenta ainda problemas com infraestrutura e baixo investimento governamental em controle sanitário.

Para 2016, a expectativa era de abertura de novos mercados e aumento das exportações. Isso elevou a produção brasileira de carne de frango em 3,8\%, subindo de 13 milhões de toneladas/ano para 13,5 milhões. Em 2015, o Brasil foi o primeiro exportador, como produtor ficou atrás dos Estados Unidos, que detinham $20 \%$ da produção mundial, enquanto Brasil e China participavam de $15 \%$, cada (AGÊNCIA BRASIL, 2015).

Dado este panorama, com a intenção de analisar os entraves políticos e econômicos impostos às exportações de frango brasileiro, é oportuno questionar se as ações do Estado brasileiro e suas políticas comerciais junto ao mercado internacional são suficientes para proteger o segmento de exportação de carne de frango.

Em termos gerais, o objetivo consiste em avaliar a atuação do Estado brasileiro em termos de políticas comerciais na defesa dos interesses do setor exportador agrícola, sob a ótica dos gestores de algumas empresas. De forma específica, primeiramente são descritos os problemas que afetam a capacidade competitiva do setor de frango do Brasil, a partir da criação da Organização Mundial do Comércio (OMC), seguido de uma breve análise das principais barreiras que dificultam a inserção no comércio internacional do setor avícola brasileiro e avaliação da atuação do estado brasileiro na defesa dos interesses do setor.

Como método para avaliação das variáveis descritas anteriormente sobre o desempenho das exportações brasileiras de carne de frango, utilizou-se a metodologia MICMAC (matriz de impacto cruzado - multiplicação aplicada à classificação), para se obter dados qualitativos por meio de pesquisas aplicadas aos gestores das áreas de exportação de algumas empresas do ramo.

Nas próximas seções estão contempladas questões que tratam da capacidade competitiva no setor de aves e as principais barreiras impostas ao frango brasileiro, seguido da apresentação do método aplicado e por fim, apresentação dos resultados e discussões da aplicação e respectivas considerações sobre as questões propostas.

\section{A CAPACIDADE COMPETITIVA NA CADEIA DE FRANGOS}


Desde o ano 2000, a carne de frango foi considerada como a melhor em competitividade (GONÇALVES et al., 2006).

Mas nem sempre o frango brasileiro esteve tão em alta. Segundo Turra (2013) dados de um estudo feito pela União Brasileira de Avicultura, apontaram que o principal gargalo da competitividade da indústria avícola nacional foram os altos custos industriais. Esses custos envolveram a mão de obra, embalagens e investimentos. A perda de competitividade brasileira nas exportações mundiais de frango deu-se principalmente pela redução da participação nas negociações internacionais. Entre 2001 e 2004 a participação do Brasil nas exportações de frango era de 30\%, entre 2005 e 2008 passou para 39\% e 37\% entre 2009 e 2012 (TURRA, 2013).

O mesmo estudo apontou ainda que a melhoria da competitividade na indústria avícola nacional passou pelo aumento da produtividade de mão de obra. Em 2013 o setor respondia por 347 mil empregos diretos. Esse custo poderia ser suprido pela modernização e automação da agroindústria brasileira, além de investimentos em mão de obra.

Mas apesar dos dados negativos apresentados, o relatório ainda se mostrou otimista indicando que o Brasil continuaria sendo o maior exportador de frango do mundo, já que um fator de alta competitividade no setor é o grande acesso aos insumos de milho e soja. No período já se previa também ajustes cambiais favoráveis, o que se comprovou no ano de $2015 \mathrm{com}$ a alta cambial favorecendo os preços do frango brasileiro nas exportações mundiais.

Em 2014 a carne de frango bateu recorde em exportação com 4,1 milhões de toneladas (VILANCULOS et al., 2015). Esse recorde considera as vendas externas de frango inteiro, cortes congelados, industrializados, carnes salgadas e miúdos.

Segundo o CEPEA (2015) (Centro de Estudos Avançados em Economia Aplicada), na média dos 15 primeiros dias de janeiro de 2015, o frango inteiro resfriado foi cotado em $R \$ 3,54 / \mathrm{Kg}$, enquanto a carcaça bovina ficou em $R \$ 9,22 / \mathrm{Kg}$ e a suína em $R \$$ $6,97 / \mathrm{Kg}$. Assim, a proteína de frango ficou, em média, 61,4\% mais barata que a carne bovina e 48,8\% que a carne suína. Ainda em janeiro do mesmo ano, o preço da carne de frango esteve em queda devido à grande disponibilidade de animais para abate, bem como a elevada quantidade de carne no atacado e no varejo.

Para o Ministério da Agricultura, Pecuária e Abastecimento (MAPA), até 2020, a expectativa é que a produção nacional de carnes suprirá $44,5 \%$ do mercado mundial. Essa estimativa coloca o Brasil como um dos maiores produtores e exportadores de carne e alimentos cárneos para mais de 200 países (MAPA, 2016).

Em 2015, o país esteve à frente de grandes nomes da exportação de frango. Foram vendidos aproximadamente $40 \%$ da proteína exigida pelo mercado mundial, seguido pelos Estados Unidos com 20\%, União Europeia com 9\%, Tailândia e China com 4\% cada um (EBC, 2015).

Para 2016, a BRF - Brasil Foods fez uma previsão de aumento da competitividade do frango do Brasil, em decorrência da desvalorização da moeda brasileira perante o dólar naquele período. Segundo o AVISITE (2015) outro fator crucial foi a redução das exportações dos Estados Unidos, causado pelo maior surto de influenza aviária dos últimos tempos, banindo o produto americano em países como Coréia, China, Rússia e Japão.

Segundo Victor Ayres, assessor técnico da Comissão Nacional de Aves e Suínos, da Confederação da Agricultura e Pecuária do Brasil (CNA), a expectativa 
era que, em 2016, a abertura de novos mercados e o aumento das exportações elevasse a produção brasileira de carne de frango em 3,8\%, subindo dos 13 milhões de toneladas/ano para 13,5 milhões. Com esse cenário comercial favorável e números econômicos tão significativos, fica difícil elencar possíveis fatores desfavoráveis à competitividade do setor de aves.

Segundo Francisco Turra para a AVISITE (2015), presidente da União Brasileira e Avicultura, a elevação dos custos com mão de obra não foi um problema em si. O problema esteve na possibilidade de perda na produtividade. Entre 2006 e 2011, a produção de carne por trabalhador cresceu $13 \%$, enquanto os salários médios subiram $19 \%$ no mesmo período. O custo elevado se deu principalmente pela dificuldade das empresas em contratar funcionários, uma vez que na época os índices de desemprego estiveram abaixo da média (AVISITE, 2015).

Segundo estudo realizado pela Agro.Icone para a ABPA - Associação Brasileira de Proteína Animal (2015), em um ampliar a automação é essencial, uma vez que a indústria avícola é bastante intensiva em mão de obra. O maior uso de máquinas se reflete diretamente na produtividade do trabalho. Zerbini afirmou ainda que o valor adicionado por trabalhador da indústria avícola brasileira corresponde a apenas um terço do verificado na indústria americana e metade do registrado na indústria alemã. EUA e Alemanha utilizam a automação de maneira mais intensiva que o Brasil. $O$ estudo defende ainda que além dos custos industriais, se não houver investimentos em logística, corre-se o risco de queda na competitividade da indústria nacional. Em 2015 o valor pago pelo trajeto da tonelada entre a indústria e o porto é de US\$ 46,80 em média. Na Tailândia, país que está ganhando espaço nas exportações, o custo da tonelada é em média US\$33. Os custos portuários no Brasil também são altos. A indústria brasileira gasta US\$22,90 por tonelada exportada, os EUA gastam US\$ 11, Tailândia gasta US\$12, 70 e França US\$ 19,20.

Os principais aspectos negativos desse contexto são a instabilidade cambial que afeta a formação de preços, taxa de juros interna, alta carga tributária e insuficiência de financiamentos, custos portuários são altos, e falta de apoio às exportações por parte do governo. O Sul do País, região pioneira na produção integrada, concentra os maiores produtores de aves do Brasil. Paraná, Santa Catarina e Rio Grande do Sul são os principais produtores e, em 2016, tiveram uma participação acima de $59 \%$ da produção nacional (GRÁFICO 1). O Paraná foi responsável por 31,02\% dessa produção. 


\section{Gráfico 1 - Produção de frangos de corte, maiores produtores e exportadores}

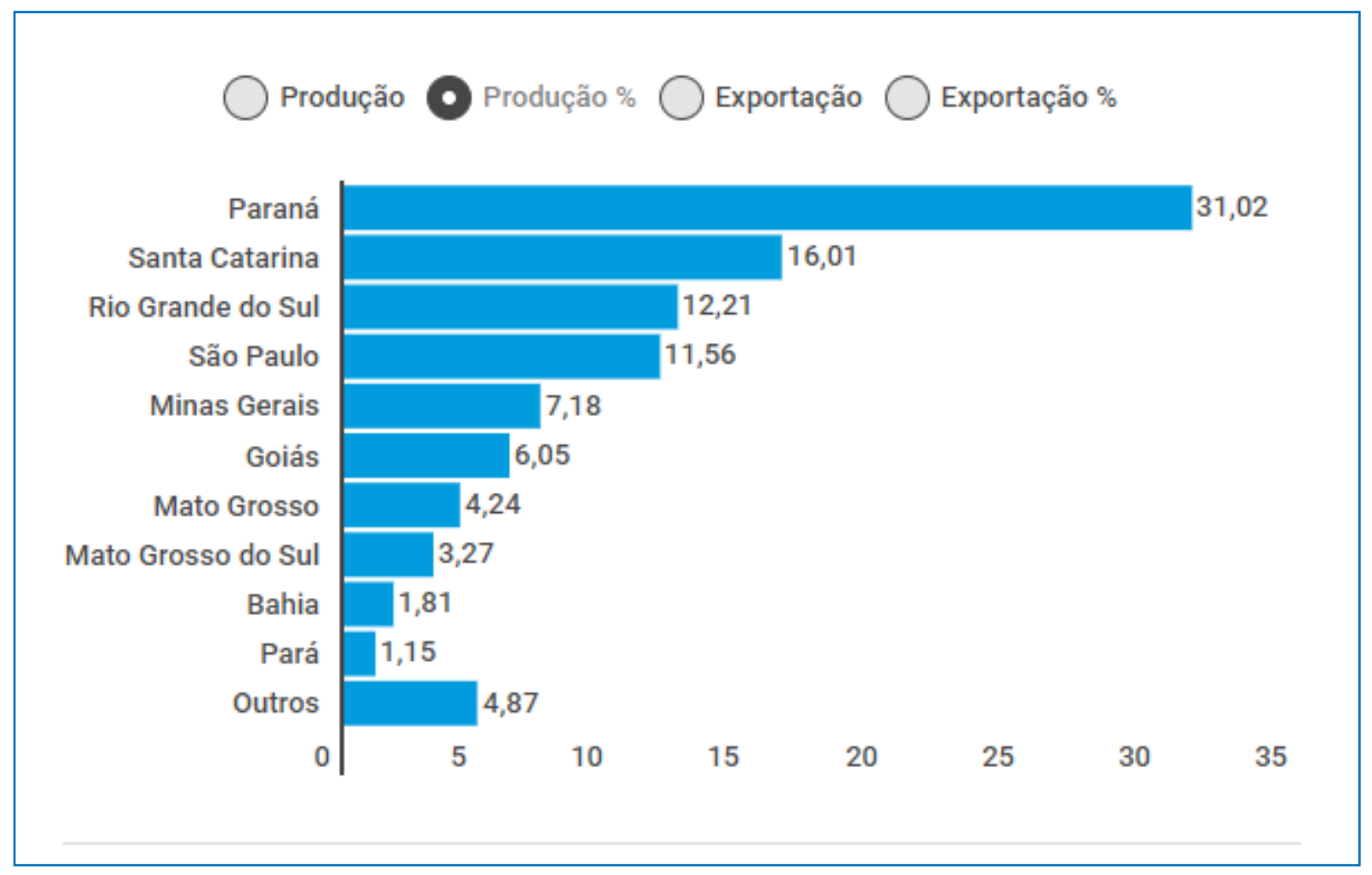

FONTE: MAPA|Agrostat

O Estado do Paraná possui ainda, cooperativas que figuram entre os maiores abatedores de aves do estado, como a COPACOL (Cafelândia), COOPAVEL (Cascavel), LAR (Medianeira) e COOPAGRIL (Marechal Cândido Rondon), além de possuir as maiores empresas do ramo do país (Sadia e Perdigão). A avicultura de corte é a atividade predominante nestas cooperativas e, tanto em tecnologia, quanto em organização da produção servem de referência nacional aos demais estados brasileiros. Cabe destacar que é pela representatividade dessa região no total da produção que a pesquisa foi aplicada aos gestores das maiores empresas dessa localidade.

A Figura 1 mostra os estados brasileiros que apresentam os maiores números de exportação de frango no Brasil. 


\section{Figura 1 - Maiores exportadores de carne em 2016}

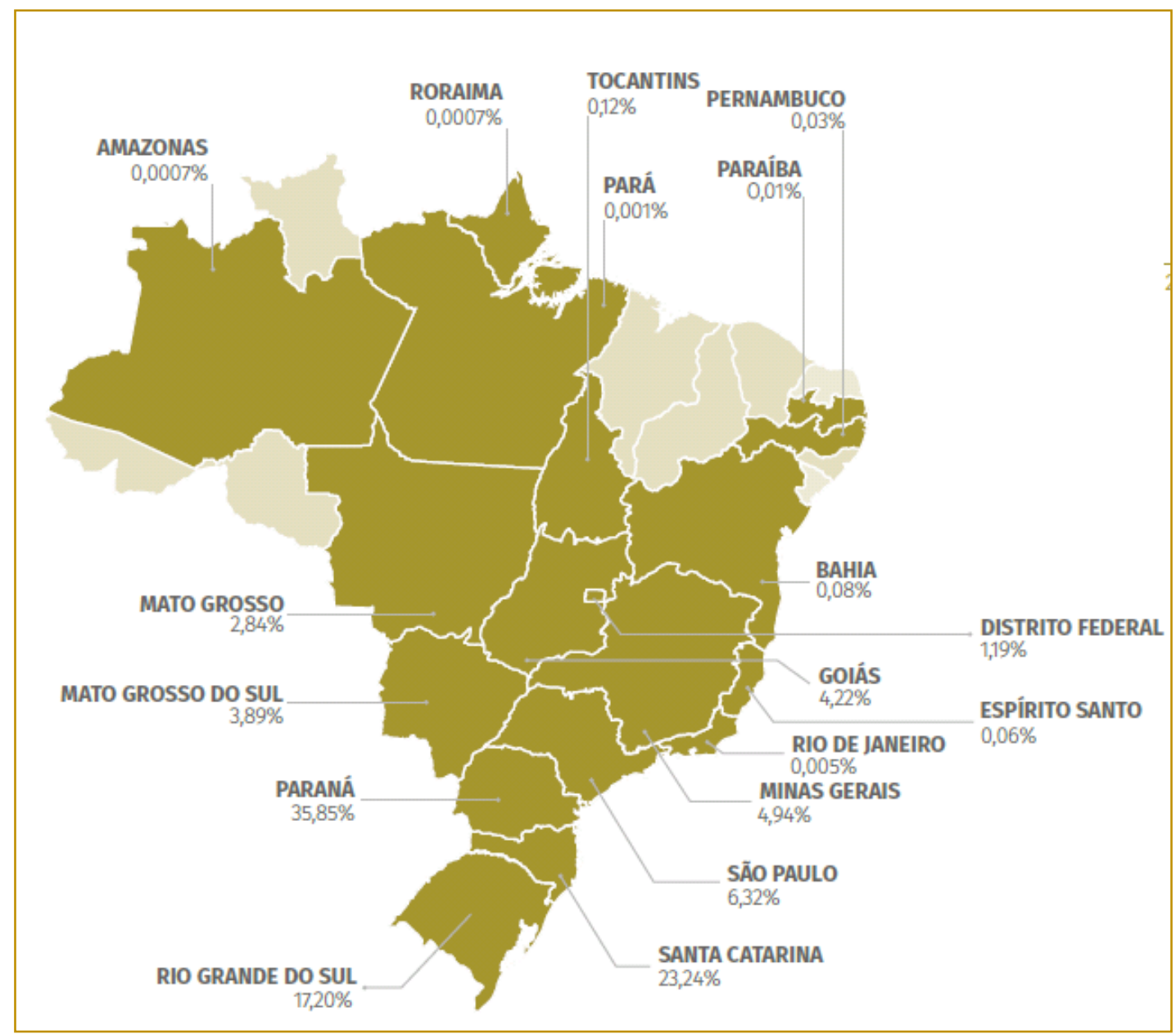

Fonte: Secex/ABPA, 2016

O Paraná possui cooperativas que figuram entre os maiores abatedores de aves do estado, como a COPACOL (Cafelândia), COOPAVEL (Cascavel), Cooperativa Agroindustrial Lar (Medianeira) e COOPAGRIL (Marechal Cândido Rondon), além de possuir as maiores empresas do ramo do país (Sadia e Perdigão). O estado foi responsável, em 2016 , por $47,17 \%$ da produção da região sul, que é responsável por $76 \%$ da produção nacional. A avicultura de corte é a atividade predominante nestas cooperativas e, tanto em tecnologia, quanto em organização da produção servem de referência nacional aos demais estados brasileiros.

\section{Barreiras à exportação de frango brasileiro}

O mercado mundial está cada vez mais exigente em relação à qualidade dos alimentos que são destinados ao consumo humano. Nesse sentido, cabe aos órgãos reguladores a função de controlar os produtos de origem animal para exportação, atestando a qualidade e segurança alimentar. Cabe ressaltar que no Brasil, o MAPA - Ministério da Agricultura, Pecuária e Abastecimento - é o responsável por realizar a ampla fiscalização com o objetivo de promover a conformidade entre a legislação de 
inspeção industrial e sanitária no Brasil com as normas de sanidade do país importador (MAPA 2012).

Considerada uma das principais barreiras para a exportação brasileira, a sanidade é a maior exigência entre os países importadores. Autores como Dias (2003), França (2006) e Faria (2009), apontam que as normas e regulamentos podem ser criados com duplo sentido. Podem ter legítima intenção e ao mesmo tempo intenção protecionista. Um exemplo simples é quando um país estabelece regras incompatíveis com os termos técnicos estabelecidos nas normas. Observa-se isso quando certas medidas são discriminatórias, adotadas com o propósito de criar obstáculos ao comércio internacional, ou quanto essa regra é restrita além do necessário para o objetivo almejado no comércio.

Os acordos sanitários estabelecem ações para proteger animais e inspeção de seus derivados. A fim de ampliar o acesso aos mercados externos com capacidade real ou potencial de consumo, o MAPA possui órgãos responsáveis pela elaboração de propostas, negociações e análise de deliberações relativas às exigências do setor. Cada produto possui procedimentos específicos que dependem das normas e diretrizes legais adotadas pelo bloco de países importadores (MAPA, 2012).

A SRI - Secretaria de Relações Internacionais do Agronegócio - atua com a criação de propostas para as negociações de acordos sanitários e fitossanitários, analisando deliberações que tratam das exigências que envolvem assuntos de interesse do setor agropecuário brasileiro. A secretaria também estimula a comercialização externa de produtos e serviços do agronegócio através de ações relacionadas ao setor. Essas ações promovem a imagem do Brasil como grande provedor de alimentos seguros e de qualidade em grandes feiras e eventos em países como Emirados Árabes, Indonésia, China, África do Sul, Arábia Saudita, Vietnã e Rússia (MAPA, 2012).

A Codex Alimentarius é um fórum internacional de normatização do comércio de alimentos estabelecido pela Organização das Nações Unidas, pela Organização para a Agricultura e Alimentação (FAO) e Organização Mundial da Saúde (OMS). Esse fórum tem como sua principal finalidade proteger a saúde do consumidor e assegurar práticas justas no comércio de alimentos. Estabelece requisitos, práticas e padrões de qualidade de um produto de maneira uniforme. As normas Codex envolvem alimentos que vão dos processados até as substâncias usadas na fabricação dos alimentos. Suas diretrizes dizem respeito aos aspectos de qualidade, higiene, aplicação e descrição do produto, norma de aditivos alimentares, pesticidas, resíduos de medicamentos veterinários, substâncias contaminantes, rotulagem, classificação, métodos de amostragem e análise de riscos (CODEX ALIMENTARIUS, 2012).

Em 2005, a União Europeia tornou obrigatória a rastreabilidade de produtos agroalimentares através do Regulamento CE 178/2002. Esse regulamento exige ações e procedimentos técnicos que permitam identificar e rastrear todos os alimentos desde o nascedouro até sua distribuição (BRASIL, 2012).

A rastreabilidade traça o histórico produtivo, localizando um item por meio de informações previamente registradas de todas as etapas do processo, até a expedição e recepção do produto. Isso garante a segurança alimentar para consumidores que não se satisfazem somente com informações genéricas sobre a ausência de riscos no consumo de alimentos. Mesmo assim, o rastreio não garante a segurança e qualidade do alimento (FRANÇA, 2006).

Certificar os sistemas de qualidade da produção de alimentos também atesta a conformidade do produto e atende às demandas de clientes internacionais, melhorando a imagem dos produtos junto aos clientes mais exigentes. As certificações 
também agregam valor e exigem cadeia transparente de ações para manter sua credibilidade. A exemplo disso, analisa-se o pelo DNA identificar do animal que servirá de matéria prima para o embutido cárneo (BRASIL, 2012).

Observa-se que a certificação do padrão de identidade e qualidade dos produtos derivados de carne é importante para detectar adulteração e proteger os consumidores quanto às questões sanitárias, econômicas e religiosa.

\section{Principais embargos às exportações brasileiras}

A Organização Mundial do Comércio (OMC) possui um conjunto de acordos com normas que regulam as relações comerciais internacionais, estabelecendo os direitos e deveres de cada um dos países membro. No entanto, estes acordos podem ter interpretações distintas ou podem ser descumpridos, gerando conflito entre esses países. Se isso acontecer, os membros devem utilizar o sistema de solução de controvérsias instituído pela OMC, para que a controvérsia seja analisada e solucionada, garantindo que todos cumpram com as normas comerciais com maior segurança jurídica ao sistema. A organização possui também um sistema de Solução de Controvérsias em assuntos de comércio. Isso trouxe maior segurança jurídica na solução dos litígios e estabelece um mecanismo eficaz no sentido de promover um maior entendimento entre os estados soberanos. A própria OMC o considera como "a pedra angular do sistema multilateral do comércio". Esse sistema tem uma série de regras que visam garantir sua eficácia, segurança e previsibilidade ao comércio internacional, preservando os direitos e deveres de seus membros.

O Brasil é um grande usuário do sistema de solução de controvérsias da OMC, estando na quarta posição do ranking dos demandantes para solução de controvérsias perante a OMC, atrás somente dos EUA, UE e Canadá. Ademais, é vencedor de controvérsias importantes como, por exemplo, o caso Embraer/Bombardier, Algodão, Açúcar, Frango, etc. (SILVEIRA, 2011).

Os acordos firmados na OMC preveem que um país, que se considere prejudicado por alguma prática de seus parceiros comerciais, deve tentar negociações bilaterais. Para isso, existem dois caminhos: introduzir medidas de defesa comercial para neutralizar o prejuízo ou recorrer ao Órgão de Solução de Controvérsias (OSC). Cada uma das disputas julgadas procedentes pela OMC, tem suas recomendações formalizadas em relatório para induzir o cumprimento dos acordos firmados ou para que o país violador forneça as compensações ao prejudicado (IEA, 2009).

Segundo o MDIC (2016), as práticas de comércio internacional consideradas desleais são o dumping, subsídios (medidas compensatórias) e salvaguardas. $\mathrm{O}$ Dumping é a prática comercial pela qual o exportador vende certo produto para o mercado externo por preço inferior ao vendido em seu mercado interno. Nesse caso, as medidas antidumping tem como objetivo comprovar a existência de dumping, dano e relação causal sendo conduzida de acordo com as regras estabelecidas pela OMC, que garantem ampla oportunidade de defesa a todos os interessados e a transparência na condução do processo.

Os subsídios são benefícios concedidos em função dos seguintes casos: que exista, no país exportador, qualquer forma de sustentação de renda ou de preços que, direta ou indiretamente, contribua para aumentar exportações ou reduzir importações de qualquer produto; ou que exista contribuição financeira por um governo ou órgão público, no interior do território do país exportador. As medidas compensatórias servem para compensar os subsídios no país exportador, direta ou indiretamente, no 
país exportador, para a fabricação, produção, exportação ou ao transporte de qualquer produto, cuja exportação ao Brasil cause danos à indústria doméstica.

Segundo o DECOM - Departamento de Defesa Comercial do MDIC, as medidas de salvaguarda servem para aumentar, temporariamente, a proteção à indústria doméstica que esteja sofrendo prejuízo grave ou ameaça de prejuízo grave decorrente do aumento das importações (em quantidade), em termos absolutos ou em relação à produção nacional, com o intuito de que durante o período de vigência de tais medidas a indústria doméstica se ajuste, aumentando a sua competitividade.

Os custos elevados em relação à nutrição animal ainda são um grande desafio. Com o dólar elevado, os preços do milho e do farelo de soja podem se manter altos, assim como os gastos com importação de outros itens para o Brasil, onde a maior parte da produção de frango é realizada pelo sistema de integração e nesse caso, os gastos com insumos que compõem a ração ficam por conta das agroindústrias. Para o avicultor restam os gastos com energia e mão de obra.

Em agosto de 2015, o Japão rompeu as barreiras com a avicultura brasileira. O país é o maior importador de ovos do mundo e serve como selo de qualidade sanitária para outros países. Esse acesso ao mercado exigente do Japão é visto como diferencial nos produtos brasileiros.

Em 2016 o cenário cambial (mercado externo) e a baixa renda do brasileiro (mercado interno) favoreceram o consumo de carne de frango. Em decorrência dos elevados preços da carne do boi e projeções nada animadoras do crescimento da economia brasileira, houve um favorecimento do consumo de proteína de frango.

Segundo o Avisite (2016), em 2016 a carne de frango brasileira chegou a 141 países, quatro a menos que em 2015. Já o volume destinado aos 25 principais importadores correspondeu a $90 \%$ do total exportado e gerou $91 \%$ da receita cambial total. (TABELA 1)

Tabela 1 - 10 Principais importadores de carne de frango (ordenado segundo volume adquirido)( Refazer ao tabela!!)

\begin{tabular}{|c|c|c|c|c|c|c|c|c|}
\hline \multicolumn{2}{|c|}{$\begin{array}{l}\text { POSI- } \\
\text { CAOO }\end{array}$} & \multirow[b]{2}{*}{$\begin{array}{c}\text { PAIS } \\
\text { IMPORTADOR }\end{array}$} & \multicolumn{3}{|c|}{ VOLUME } & \multicolumn{3}{|c|}{ RECEITA } \\
\hline $\begin{array}{l}2 \\
0 \\
1 \\
6 \\
\end{array}$ & $\begin{array}{l}2 \\
0 \\
1 \\
5 \\
\end{array}$ & & MIL/T & $\begin{array}{l}\text { VAR. } \\
\text { ANUAL }\end{array}$ & $\begin{array}{c}\% \text { DO } \\
\text { TOTAL }\end{array}$ & $\begin{array}{l}\text { USS } \\
\text { MIL }\end{array}$ & $\begin{array}{l}\text { VAR. } \\
\text { ANUAL }\end{array}$ & $\begin{array}{l}\text { \% DO } \\
\text { TOTAL }\end{array}$ \\
\hline 1 & 1 & Arábia Saudita & 746,4 & $-5,43 \%$ & $17,32 \%$ & $1.157,2$ & $-15,50 \%$ & $17,11 \%$ \\
\hline 2 & 3 & China & 484,5 & $57,80 \%$ & $11,25 \%$ & 860,4 & $41,60 \%$ & $12,72 \%$ \\
\hline 3 & 2 & Japão & 397,1 & $-5,60 \%$ & $9,22 \%$ & 729,7 & $-13,35 \%$ & $10,79 \%$ \\
\hline 4 & 4 & Emirados Arabes & 301,6 & $-0,69 \%$ & $7,00 \%$ & 478,4 & $-6,10 \%$ & $7,07 \%$ \\
\hline 5 & 5 & Hong Kong & 248,7 & $5,24 \%$ & $5,77 \%$ & 357,4 & $21,82 \%$ & $5,28 \%$ \\
\hline 6 & 6 & Africa do Sul & 221,9 & $5,91 \%$ & $5,15 \%$ & 98,7 & $-7,36 \%$ & $1,46 \%$ \\
\hline 7 & 7 & Holanda & 181,8 & $-5,62 \%$ & $4,22 \%$ & 402,1 & $-12,69 \%$ & $5,95 \%$ \\
\hline 8 & 9 & Kuwait & 108,5 & $-10,78 \%$ & $2,52 \%$ & 163,0 & $-15,15 \%$ & $2,41 \%$ \\
\hline 9 & 13 & Cingapura & 97,4 & $16,74 \%$ & $2,26 \%$ & 185,2 & $14,09 \%$ & $2,74 \%$ \\
\hline 10 & 18 & Egito & 97,2 & $39,73 \%$ & $2,26 \%$ & 140,2 & $28,21 \%$ & $2,07 \%$ \\
\hline
\end{tabular}

Fonte: Avisite, 2016

A Arábia Saudita - um dos primeiros países alcançados pelo frango brasileiro - manteve a posição de importador líder, absorvendo $17 \%$ de todo o volume exportado. (TABELA 1) A alta do dólar tem levado os produtores de carne de frango 
a obter ganhos maiores na troca direta com o mercado internacional. Um ganho auxiliado, de acordo com a ABPA, pela abertura de novos mercados para carne, ovos e material genético (BRASIL, 2016). Em reportagem produzida pelo G1 (2017), o Brasil produziu em 2016, 12,9 milhões de toneladas de carne de frango e exportou 4,38 milhões de toneladas (US\$6 bilhões), sendo o maior exportador mundial e o $2^{\circ}$ maior produtor, atrás dos EUA.

\section{ASPECTOS METODOLÓGICOS}

Para a compreensão do comportamento das variáveis que compõem um sistema-objeto, Godet (1993) apresenta a metodologia de análise estrutural MICMAC, (Matriz de Impactos Cruzados - Multiplicação Aplicada à Classificação). Esse método tem por objetivo analisar as variáveis internas que formam o sistema-objeto. Nesse caso, o sistema é composto pelas políticas de exportação, assim como as variáveis externas, que, de alguma forma interagem com o sistema em estudo. Marcial e Grumbach (2004) também descrevem esse método. O caso de estudo aqui apresentado utilizou o aplicativo MICMAC®, desenvolvido pelo Laboratório de Pesquisa em Estratégia Prospectiva e Organizacional (LIPSOR, 2004).

Para o método de análise estrutural MICMAC, selecionam-se as variáveis consideradas mais importantes para a descrição do sistema-objeto. O método MICMAC permite uma hierarquização de variáveis em função da influência direta e indireta que cada variável exerce sobre outra. Outra informação que pode ser obtida por meio do método MICMAC é o comportamento das variáveis em estudo quanto à sua motricidade e à sua dependência no interior do sistema. Segundo Netto e Vergara (2007), a motricidade de uma variável indica o quanto essa variável consegue impor seu comportamento em relação às outras variáveis do sistema, onde uma variável com alta motricidade tende a reger o desempenho do sistema ao qual pertence ou com o qual interage. Ainda para os autores, a dependência indica o quanto a variável em questão sofre influência no seu comportamento em relação às outras variáveis: o comportamento de uma variável com alta dependência pode ser um indicativo do desempenho das variáveis com alta motricidade.

A entrada de dados é feita por meio da construção da matriz de influência direta (do tipo variável $x$ variável), preenchida pelo usuário. Para preenchimento da matriz de influência direta, adotam-se valores de zero a três, sendo: 0 - Não existe influência; 1 - Influência fraca; 2 - Influência mediana; 3 - Influência forte.

A matriz é preenchida da linha para a coluna em que é indicada a influência que a variável da linha exerce nas variáveis das colunas. Netto e Vergara (2007) estabelecem que a diagonal principal é sempre nula uma vez que não se considera a influência da variável sobre ela mesma. Após o preenchimento da matriz, somam-se os valores das linhas e das colunas. O valor das linhas indica a força que essa variável exerce no sistema, ou seja, quanto maior o valor maior é a motricidade da variável. $\mathrm{O}$ valor das colunas indica o grau de dependência da variável, quanto maior o valor, maior é a influência que essa variável recebe do sistema.

Para verificação da influência indireta, realizam-se multiplicações sucessivas da matriz de influência direta por ela mesma até a sequência de ordenamento dependência) permaneça estável, ou seja, não se altere mais. A classificação das variáveis segue o mesmo procedimento utilizado na influência direta.

De posse dos resultados da influência direta e indireta, analisa-se o comportamento das variáveis nessas duas situações. Podem ocorrer casos em que uma variável na influência direta pode não parecer motriz e, após uma análise de

32 Economia \& Região, Londrina (Pr), v.6, n.1, p.23-45, jan./jun. 2018 
influência indireta, possa se detectar uma maior motricidade, o que pode colocá-la em uma posição de destaque e relevância dentro do sistema em estudo. Essa análise é feita comparando os mapas de influência/dependência direta e indireta.

Os gráficos gerados pelo aplicativo MICMAC representam a relação direta/indireta entre as variáveis, por meio de linhas cuja cor varia em função da intensidade dessa influência.

Esse método possibilita, promover processo de planejamento estratégico a partir da consideração de um dado cenário como um sistema, descrito por variáveis, que interagem com outros sistemas e suas variáveis, avaliando-se como essas variáveis se comportam e interagem entre si.

O método proposto mostra-se potencialmente pertinente para o processo de auxílio na decisão do estado e na gestão da exportação de frango, pois permite a representação adequada do sistema, evidenciando relações entre variáveis e questões, que poderiam não ser percebidas, caso se optasse por uma abordagem não estruturada de representação de sistemas. Deve-se considerar, no entanto, a subjetividade na seleção dos dados de entrada e na análise dos resultados, assim como a emissão de juízos de valor inerentes ao método.

\section{$1 \quad 4.1$ OS RESULTADOS DA PESQUISA DE CAMPO}

Com base nas pesquisas de campo, realizadas a partir de entrevistas com 5 especialistas da área de mercado exterior, das empresas exportadoras da região oeste do Paraná, foram levantadas 17 variáveis relevantes à nossa análise. A Tabela 2 apresenta a relação destas variáveis dentro do sistema MICMAC, no momento em que são elencadas afim de atribuir valores de influência reciproca entre elas, e rodar o referido programa. 
Tabela 2 - Variáveis usados no software MICMAC

\begin{tabular}{|c|c|c|c|}
\hline $\mathbf{N}^{\circ}$ & Long label & $\begin{array}{l}\text { Short } \\
\text { label }\end{array}$ & Description \\
\hline 1 & \begin{tabular}{|l|}
$\begin{array}{l}\text { Barreiras religiosas } \\
\text { HALAL }\end{array}$ \\
\end{tabular} & B.Relig. & $\begin{array}{l}\text { Exigência dos países mulçumanos para a compra de } \\
\text { carnes, seguindo os preceitos da religião hislâmica. }\end{array}$ \\
\hline 2 & Barreiras Sanitárias & B.Sanit. & 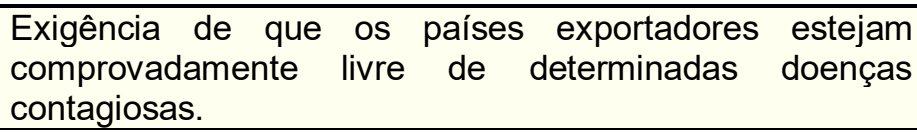 \\
\hline 3 & Barreiras Tarifárias & B.Tarif. & $\begin{array}{l}\text { Taxas impostas pelos países compradores, aos produtos } \\
\text { importados, estas taxas sofrem aumentos significativos } \\
\text { quando os volumes ultrapassam determinada cota } \\
\text { estipulada. }\end{array}$ \\
\hline 4 & Barreiras Técnicas & B.Téc. & $\begin{array}{l}\text { Certificações, das mais variadas, que são exigidas por } \\
\text { determinados países, visando dificultar a entrada de } \\
\text { produtos. }\end{array}$ \\
\hline 5 & $\begin{array}{l}\text { Burocracia Interna } \\
\text { MAPA }\end{array}$ & Bur.Int. & $\begin{array}{l}\text { A legislação brasileira é bastante complexa e as vezes } \\
\text { causa re-trabalho, com fiscalização internas da indústria } \\
\text { sendo repetidas no momento do embarque, no porto. }\end{array}$ \\
\hline 6 & Câmbio Instável & Câmbio & $\begin{array}{l}\text { O câmbio é uma variável extremamente importante nos } \\
\text { negócios internacionais e esta insegurança impossibilita o } \\
\text { fechamento de contratos de longo prazo. }\end{array}$ \\
\hline 7 & Carga Tributária Alta & C.Tribut. & $\begin{array}{l}\text { Os tributos sobre a produção, no Brasil, são um dos mais } \\
\text { altos do mundo, o que dificulta nossa competitividade. }\end{array}$ \\
\hline 8 & $\begin{array}{l}\text { Cotas } \\
\text { Importações }\end{array}$ & Cotas & $\begin{array}{l}\text { Imposição de limites de volume de importação por país, } \\
\text { toda vez que este limite é ultrapassado as tarifas cobradas } \\
\text { sofrem aumentos exorbitantes. }\end{array}$ \\
\hline 9 & \begin{tabular}{|l|} 
Custos \\
Infraestrutura \\
Portuária \\
\end{tabular} & Portos & $\begin{array}{l}\text { Os custos de uso das estruturas portuárias, no Brasil, estão } \\
\text { entre os mais altos do mundo, além de serem morosas e } \\
\text { obsoletas. }\end{array}$ \\
\hline 10 & Custos Industriais & C.Ind. & $\begin{array}{l}\text { Os custos industriais brasileiros, que } \\
\text { investimentos na infraestrutura, mão de obra e } \\
\text { embalagens, são crescentes em relação aos nossos } \\
\text { principais concorrentes, al longo dos anos. }\end{array}$ \\
\hline 11 & $\begin{array}{l}\text { Custos Trabalhistas } \\
\text { Altos }\end{array}$ & C.Trab. & $\begin{array}{l}\text { A lesgilação brasileira impõe uma carga tributária bastante } \\
\text { alta sobre a remuneração dos trabalhadores, onerando as } \\
\text { indústrias, que são intensivas em mão de obra, com pouca } \\
\text { automação. }\end{array}$ \\
\hline 12 & $\begin{array}{l}\text { Infraestrutura } \\
\text { Logística Ruim }\end{array}$ & Infr.Log. & $\begin{array}{l}\text { Estradas, porto e ferrovias sucateadas e insuficientespara } \\
\text { atender as demandas, além de custos extremamente } \\
\text { elevados em relação aos nossos concorrentes diretos. }\end{array}$ \\
\hline 13 & $\begin{array}{l}\text { Instabilidade dos } \\
\text { Custos dos Insumos }\end{array}$ & Inst.Ins. & $\begin{array}{l}\text { A falta de preocupação e planejamento com o } \\
\text { abastecimento interno tem feito com que as exportações } \\
\text { de grão causem desequilíbrio na oferta interna, elevando } \\
\text { os preços e dificultando a produção. }\end{array}$ \\
\hline 14 & Legislação Complexa & Leg.Compl & $\begin{array}{l}\text { Grande número de papéis, formulários e setores para a } \\
\text { tramitação e liberação de novas plantas e produtos. }\end{array}$ \\
\hline 15 & $\begin{array}{l}\text { Legislações } \\
\text { Específicas }\end{array}$ & Leg.Espec & $\begin{array}{l}\text { Exigência própria de cada país importador, nem sempre } \\
\text { legítimas e usadas pura e simplesmente para dificultar ou } \\
\text { retardar a entrada de produtos estrangeiros. }\end{array}$ \\
\hline 16 & Lentidão do Sistema & Lent.Sis. & $\begin{array}{l}\text { Todos os processos internos de regulamentação são muito } \\
\text { morosos, com grandes dificuldades para registro e } \\
\text { adequação de novos produtos. }\end{array}$ \\
\hline 17 & \begin{tabular}{|l} 
Resíduos \\
Alimentos \\
Transgênicos
\end{tabular} & Res.Trans. & $\begin{array}{l}\text { Alguns países exigem que os alimentos utilizados na } \\
\text { produção sejam livres de cerais transgênicos, com o uso } \\
\text { exclusivo de grão convencionais. }\end{array}$ \\
\hline
\end{tabular}

Fonte: O autor (2016). 
Todas as 17 variáveis relacionadas são confrontadas entre si, em uma matriz quadrada, onde são atribuídos graus de influência entre elas. Os valores atribuídos ao peso de influência exercido de uma variável sobre a outra, são de 0 (zero) a 3 (três), sendo:

0 (zero), quando a variável não exerce influência nenhuma sobre a outra,

1 (um), quando a influência exercida existe, porém é fraca,

2 (dois), quando a influência exercida pela variável é mediana e

3 (três), quando a influência exercida é forte.

Desta forma a distribuição das influências exercidas entre as variáveis pode ser verificada na tabela 3.

Tabela 3 - Matriz quadrada do software MICMAC

\begin{tabular}{|c|c|c|c|c|c|c|c|c|c|c|c|c|c|c|c|c|c|c|}
\hline & . & 1: & 9. $2: 8$ & $3: 8$ & $4: 8$ & $5: \mathrm{E}$ & $6: C$ & $7: C$ & $8: 0$ & $9: F$ & $10:$ & 11: & 12: & 13 & I 14: & 15: & 16: & 17 \\
\hline \multirow[t]{17}{*}{ D } & 1 : B.Relig. & 0 & 0 & 0 & 2 & 1 & 0 & 0 & 0 & 1 & 1 & 1 & 0 & 0 & 1 & 3 & 0 & 0 \\
\hline & 2: B.Sanit. & 0 & 0 & 1 & 0 & 2 & 0 & 0 & 2 & 1 & 1 & 1 & 0 & 0 & 2 & 3 & 3 & 0 \\
\hline & 3: B.Tarif. & 0 & 0 & 0 & 0 & 2 & 0 & 2 & 3 & 1 & 1 & 1 & 0 & 0 & 2 & 3 & 3 & 0 \\
\hline & 4 : B.Téc. & 1 & 3 & 0 & 0 & 2 & 0 & 0 & 3 & 2 & 2 & 1 & 0 & 0 & 3 & 3 & 3 & 3 \\
\hline & 5: Bur.Int. & 2 & 3 & 2 & 2 & 0 & 0 & 2 & 1 & 2 & 2 & 2 & 0 & 0 & 3 & 0 & 3 & 2 \\
\hline & 6: Câmbio & 0 & 0 & 2 & 0 & 0 & 0 & 2 & 1 & 3 & 1 & 2 & 2 & 3 & 1 & 0 & 2 & 0 \\
\hline & $7:$ C.Tribut. & 0 & 0 & 0 & 0 & 0 & 2 & 0 & 0 & 3 & 3 & 3 & 1 & 0 & 3 & 0 & 0 & 0 \\
\hline & 8: Cotas & 0 & 0 & 3 & 0 & 0 & 1 & 1 & 0 & 1 & 0 & 1 & 0 & 0 & 2 & 0 & 0 & 0 \\
\hline & 9: Portos & 0 & 0 & 0 & 0 & 0 & 0 & 0 & 0 & 0 & 0 & 0 & 0 & 0 & 0 & 0 & 0 & 0 \\
\hline & $10:$ C.Ind. & 0 & 0 & 0 & 0 & 0 & 0 & 0 & 0 & 0 & 0 & 0 & 0 & 0 & 0 & 0 & 0 & 0 \\
\hline & 11 : C.Trab. & 0 & 0 & 0 & 0 & 0 & 0 & 0 & 0 & 0 & 0 & 0 & 0 & 0 & 0 & 0 & 0 & 0 \\
\hline & 12 : Infr.Log. & 0 & 0 & 0 & 0 & 0 & 0 & 0 & 0 & 0 & 0 & 0 & 0 & 0 & 0 & 0 & 0 & 0 \\
\hline & 13 : Inst.Ins. & 0 & 0 & 0 & 0 & 0 & 0 & 0 & 0 & 0 & 0 & 0 & 0 & 0 & 0 & 0 & 0 & 0 \\
\hline & 14 : Leg.Compl. & 0 & 0 & 0 & 0 & 0 & 0 & 0 & 0 & 0 & 0 & 0 & 0 & 0 & 0 & 0 & 0 & 0 \\
\hline & 15: Leg.Espec. & 0 & 0 & 0 & 0 & 0 & 0 & 0 & 0 & 0 & 0 & 0 & 0 & 0 & 0 & 0 & 0 & 0 \\
\hline & 16 : Lent.Sis. & 0 & 0 & 0 & 0 & 0 & 0 & 0 & 0 & 0 & 0 & 0 & 0 & 0 & 0 & 0 & 0 & 0 \\
\hline & 17 : Res.Trans. & 0 & 0 & 0 & 0 & 0 & 0 & 0 & 0 & 0 & 0 & 0 & 0 & 0 & 0 & 0 & 0 & 0 \\
\hline
\end{tabular}

Fonte: O autor, com o auxílio do software MICMAC (2016).

Após atribuir-se os pesos às interações entre as variáveis mais importantes a serem analisadas, o programa MICMAC estabelece as correlações entre elas e as apresenta na forma de gráfico e mapa. Na Figura 2, a seguir, tem-se as inter-relações estabelecidas, apresentadas em um mapa de influência direta. O modelo é detalhado e demonstra os diferentes graus de influência e dependência seguindo uma metodologia fácil de visualizar. As linhas apresentadas no mapa, que demonstram os diferentes graus de influência e dependência apresentam cores espessuras e texturas diferentes, com vistas a facilitar este entendimento, como segue:

- Influência muito fraca - linha preta tracejada

- Influência fraca - linha preta contínua

- Influência média - linha azul fina

- Influência relativamente importante - linha azul grossa

- Influência muito importante - linha vermelha 
Figura 2 - Relações entre as variáveis de influência direta

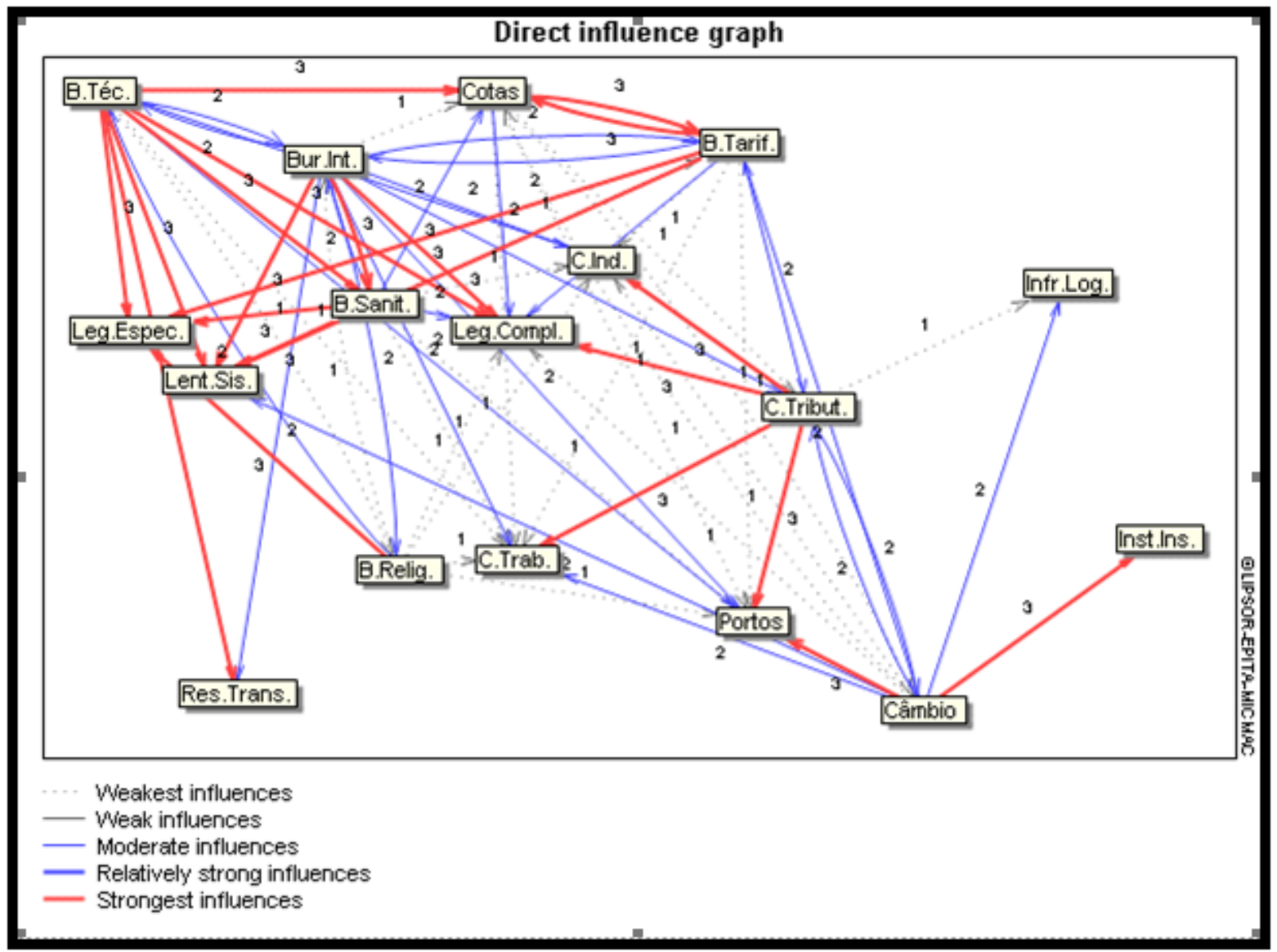

Fonte: O autor, com o auxílio do software MICMAC (2016)

O gráfico apresentado pelo programa é de fácil compreensão e autoexplicativo, por isso se tornam evidentes as variáveis que mais influenciam o modelo analisado, fazendo desta ferramenta instrumento viável e relevante aos estudos da prospectiva estratégica.

- Análise de Influência Direta entre as Variáveis

As variáveis mais influentes são a carga tributária, que afeta direta e indiretamente muitas outras variáveis, juntamente com as barreiras tarifárias e as barreiras técnicas, apresentam o maior número de interações com as demais variáveis do sistema. Existem as que sofrem bastante influência diretas sem, no entanto, afetar as demais estruturas analisadas como a de legislação específica e a de legislação complexa. As cotas e barreiras tarifárias exercem fortes influência mútuas, denotando a grande interdependência existente entre ambas, como se vê na Figura 3, abaixo. 
Figura 3 - Principais variáveis de influência direta

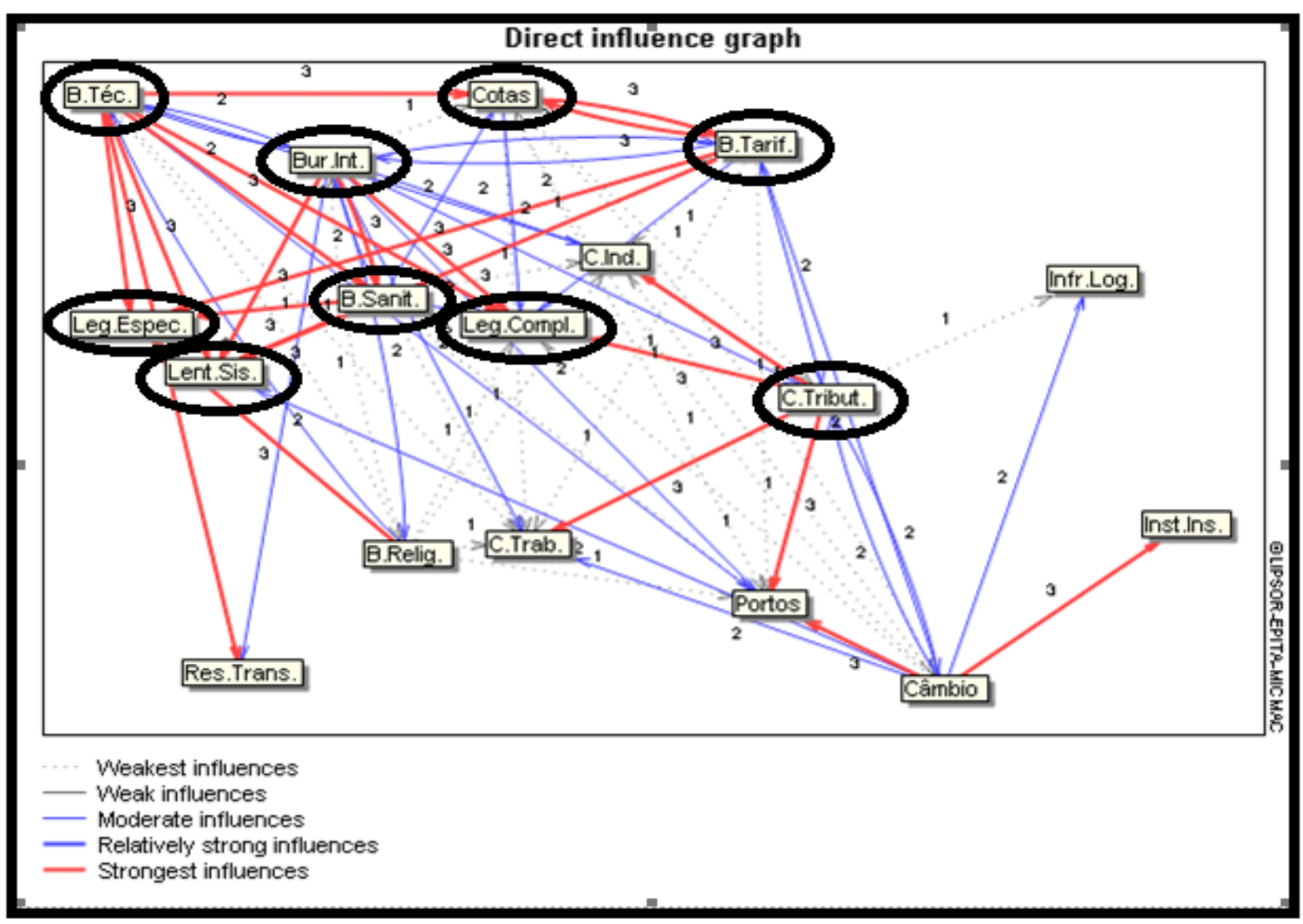

Fonte: O autor, com o auxílio do software MICMAC (2016)

Os dados destacados pelos entrevistados reiteram a visão dos textos discutidos ao longo do trabalho, com exceção da grande importância dado a carga tributária, o que se explica pelo fato de os gestores estarem preocupados mais com questões intra firma, já que os entrevistados representam a indústria. Por outro lado, essa preocupação micro representa também uma preocupação deste trabalho, qual seja, os setores envolvidos na produção não têm a correta percepção do que realmente afeta a competitividade da empresa no contexto internacional. Redução de carga tributária não fará diferença frente a elevação de barreiras não tarifárias, por exemplo.

- Avaliação do Plano de Influência e Dependência Direta

Através da análise estrutural prospectiva temos a chance de visualizarmos de forma clara, em um mapa planificado, os espaços ocupados pelas variáveis, segundo o grau de dependência e / ou influência que estes exercem sobre os demais. Desta forma como vemos na figura 4, o mapa apresenta 5 setores, que são descritos por Godet e colaboradores (2011), da seguinte maneira, a facilitar nosso entendimento: 
Figura 4 - Mapa de influência e dependência - pós análise

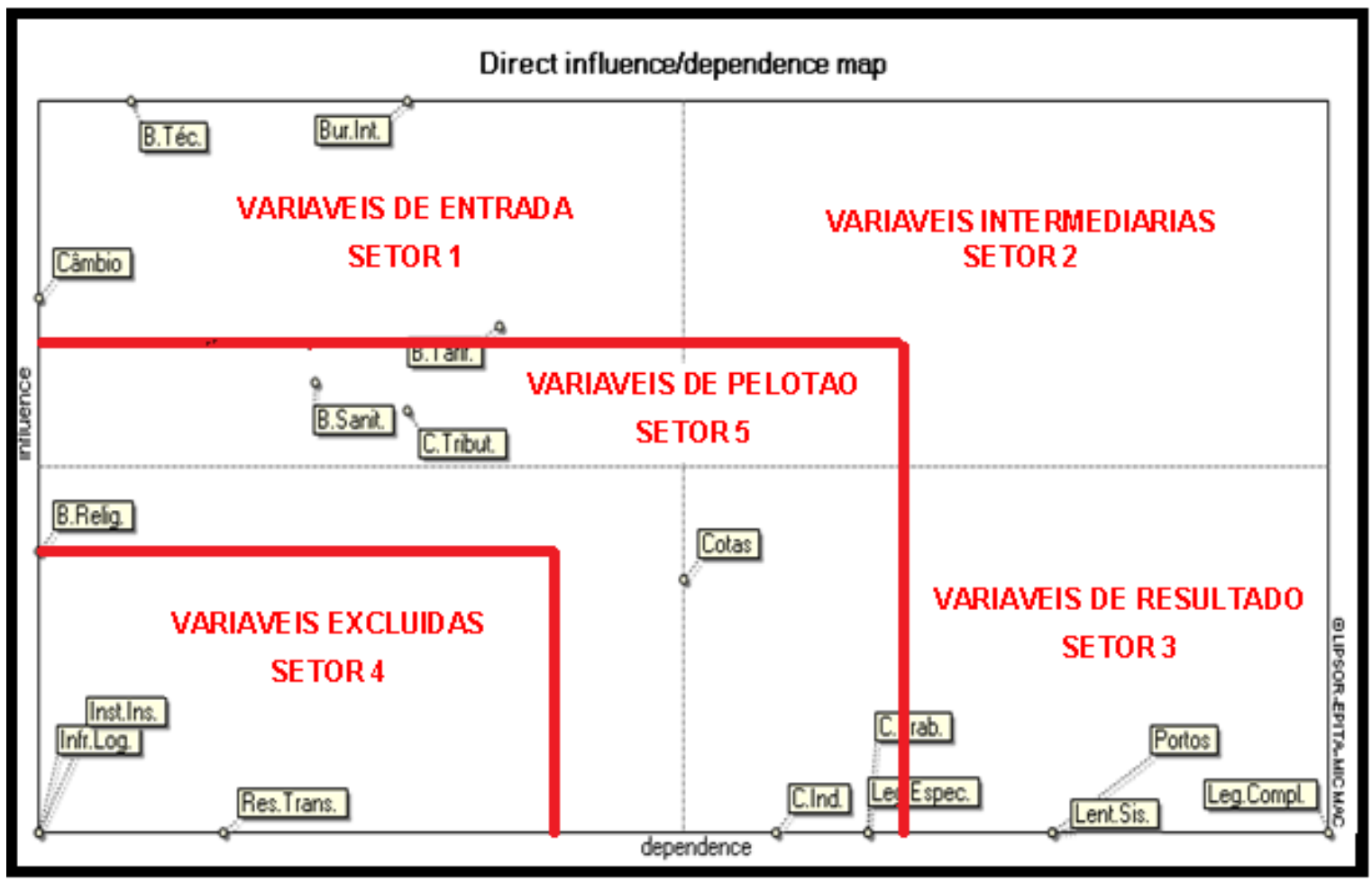

Fonte: O autor, com o auxílio do software MICMAC (2016)

- $\quad$ Localizadas no setor 1 - Variáveis explicativas ou motrizes.: São variáveis forte motrizes e fraca dependentes, são as que condicionam todo o sistema.

- $\quad$ Localizadas no setor 2 - Variáveis intermediárias ou de ligação: Qualquer ação sobre estas variáveis terá efeito significativo sobre outras variáveis do sistema e sobre si própria, o que afeta consideravelmente os dados a serem analisados.

- $\quad$ Localizadas no setor 3 - Variáveis de resultado: A evolução destas variáveis é explicada pelo comportamento das variáveis analisadas nos setores 1 e 2 .

- Localizadas no setor 4 - Variáveis excluídas: Estas interagem pouco no sistema, assim não são consideradas determinantes na influência do modelo, são fraca motrizes e fraca dependentes.

- $\quad$ Localizadas no setor 5 - Variáveis de pelotão: Estas são de difícil análise devido à zona que ocupam no mapa, já que ocupam uma região mediana, apresentam a característica de serem medianamente motrizes e medianamente dependentes.

Diante do exposto foram determinadas que 4 variáveis podem ser descartadas do plano de análise, são elas: Barreiras religiosas, infraestrutura logística, instabilidade nos custos dos insumos e resíduos de alimentos transgênicos. Tais variáveis se mostram muito isoladas e somente ações muito pontuais seriam capazes de afeta-las de forma direta, portanto parece natural que sejam excluídas por exercer pouca ou nenhuma influência e relevância para o estudo. (FIGURA 4)

Os dados anteriores conduzem a uma reflexão, se realmente os empresários e gestores do mercado de exportação estão enxergando de forma ampla e clara todas as nuances deste mercado, uma vez que a infraestrutura logística foi relegada a um segundo plano, quando esta varável é de extrema relevância para a análise dos custos da exportação e consequentemente da competitividade deste mercado. 
As variáveis pelotão, que se encontram no setor 5 , são as barreiras sanitárias, carga tributária, cotas, custo industrial, custos trabalhistas e legislações específicas, todas estas são consideradas em transição, e exercem influência mediana sobre as demais, assim como sofrem influência nas mesmas proporções.

No setor 1 tem-se as variáveis de entrada, que neste caso específico apresenta quatro variáveis, que são: Barreiras técnicas, burocracia interna, câmbio e barreiras tarifárias, estas são motrizes, muito influentes e pouco dependente das demais.

No caso estudado pode-se observar que nenhuma variável se encontra no setor 2, as variáveis aí localizadas seriam de ligação ou intermediárias, as quais geralmente possuem comportamento instável e servem de elo nos processos de influência de algumas variáveis em relação a outras.

Finalmente são analisadas as variáveis do setor 3 , ou variáveis de resultado, quais sejam: Portos, lentidão do sistema e legislação complexa. Estas variáveis são ao mesmo tempo pouco motrizes e bastante dependentes, suas ações são avaliadas a partir do comportamento das variáveis localizadas nos quadrantes 1 e 2, portanto, nosso caso específico, evidencia-se somente o quadrante 1 , já que o 2 permaneceu vazio após a execução do programa.

- Avaliação das Influências Indiretas entre as Variáveis

Na Figura 5 verifica-se que existem inúmeras inter-relações ocorrendo de forma indireta no sistema e isto demonstra que mesmo quando as relações diretas não existem entre determinadas variáveis, as mesmas podem agir e influenciar indiretamente as outras variáveis do sistema. Estão destacadas, para melhor visualização, as duas variáveis que representam maior influência indireta, legislação complexa e burocracia interna, porém existe também uma forte influência exercida pela variável barreiras técnicas, atingindo fortemente muitas outras variáveis do sistema. Estão destacadas, para melhor visualização, as duas variáveis que representam maior influência indireta, legislação complexa e burocracia interna, porém existe também uma forte influência exercida pela variável barreiras técnicas, atingindo fortemente muitas outras variáveis do sistema. 
Figura 5 - Principais Variáveis de influência indireta

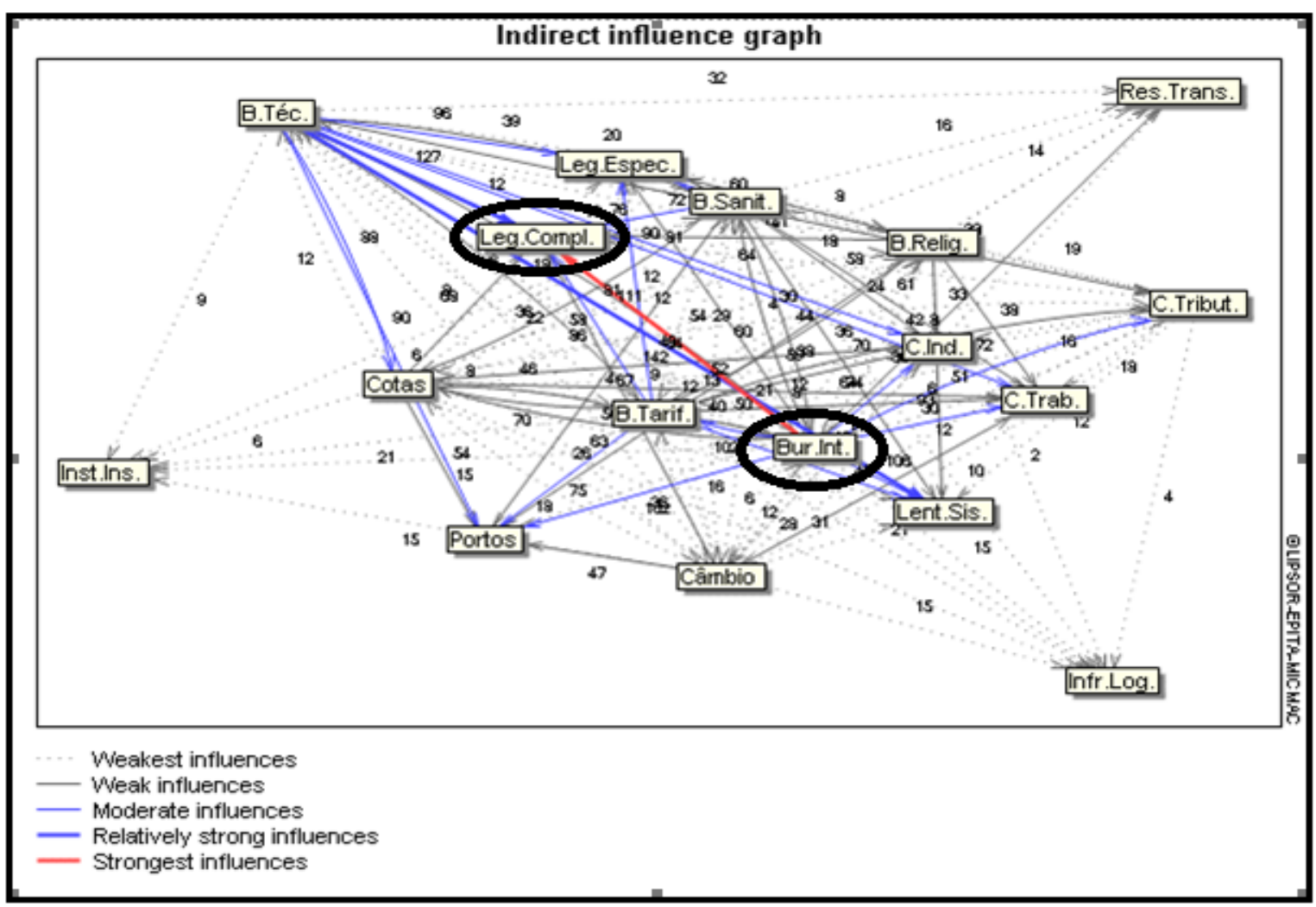

Fonte: resultados da pesquisa, com o auxílio do software MICMAC (2016).

Para a identificação das inúmeras interações diretas e indiretas do sistema, o mesmo passa por várias multiplicações sucessivas da matriz MID (matriz de impacto direto), até que atinja a estabilidade plena esperada. Na tabela 3 pode-se verificar o grau de estabilidade, nos padrões influência e dependência, obtidos após a estabilização do sistema proposto.

Tabela 4 - Estabilidade da Matriz MID

\begin{tabular}{|lll|}
\hline Interation & Influence & Dependence \\
1 & $100 \%$ & $97 \%$ \\
2 & $108 \%$ & $102 \%$ \\
\hline
\end{tabular}

Fonte: resultados da pesquisa, com o auxílio do software MICMAC (2016)

\subsection{1.4 Avaliação do Plano de Influência e Dependência Indireta}

Uma vez alcançado o equilíbrio esperado no sistema, pode-se analisar o gráfico de influência e dependência indireta, encontrado na Figura 6. 
Figura 6 - Mapa de influência e de dependência indireta

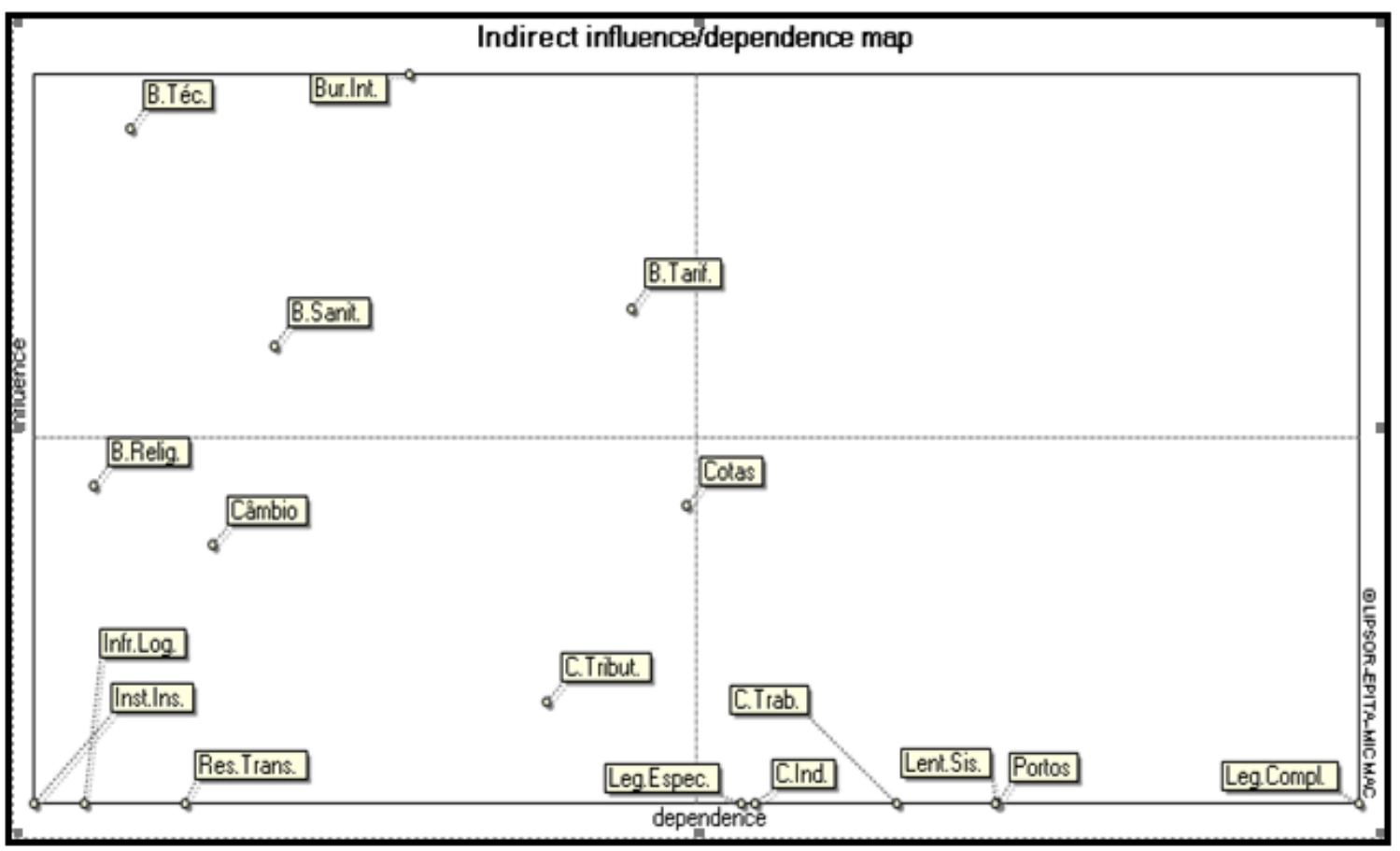

Fonte: resultados da pesquisa, com o auxílio do MICMAC (2016).

O mapa mostra que são mínimas as variações existentes entre este, e o mapa de dependência e influência direta, analisado anteriormente. Observa-se ainda que a variável carga tributária se desloca para a direita e atinge a região do setor 3 , saindo de sua antiga posição de variável de pelotão, denotando configuração de um sistema instável, onde as relações indiretas do sistema não ficam bem definidas e visíveis, porém continuam de fundamental importância, uma vez que suas ações ainda interferem no modelo.

\section{RESULTADOS E DISCUSSÕES}

O mercado internacional de frangos ocupa lugar de destaque, projeta o Brasil como segundo maior produtor e maior exportador mundial, fornecendo ao mundo uma proteína acessível, de alta qualidade, quando o mundo mais precisa dela.

Considerando o dinamismo do mercado e a velocidade em que as coisas acontecem atualmente na economia mundial, cada vez mais a competição se mostra mais acirrada, de forma que as decisões devem ser ágeis e assertivas, não havendo espaço para dúvidas; os gestores, tomadores de decisões devem ser firmes e diretos no momento da escolha dos rumos a serem seguidos nas ações de mercado, para isso precisam estar munidos de ferramentas que os auxiliem na tomada destas decisões.

A ferramenta de prospecção estratégica, MICMAC, se mostra relevante dentro deste contexto, pois trabalha com uma gama de variáveis, eleitas por especialistas no assunto, cruzando tais informações de forma inteligente e singular, extraindo as melhores possibilidades de análise gestão, escolhendo os pontos mais relevantes a serem atacados no momento da tomada de decisão. 
Quanto aos objetivos específicos levantados no início este trabalho, pode-se concluir que foram levantadas as principais barreiras que dificultam a penetração do Brasil nos diferentes mercados internacionais, estas variáveis foram descritas e elencadas pelos gestores entrevistados, especialistas que são no assunto discutido e cruzadas pelo sistema MICMAC, demonstrando em última análise quais as mais relevantes e portanto mais urgentes a serem atacadas, afim de facilitar todos os processos deste complexo mercado.

Em resposta ao questionamento levantado na introdução desse trabalho, o estado brasileiro tem grandes passos a serem percorridos, e muito se deve fazer em várias frentes para que se possa atingir os objetivos almejados no mercado internacional de carnes de frango. Das questões levantadas pelo sistema, como mais relevantes a serem atacadas, algumas são internas, inerentes ao próprio país, onde deve-se atacar fortemente afim de neutralizarmos os efeitos danosos destes erros ocorridos internamente, outros, porém são de cunho externo e estes devem ser negociados no âmbito internacional, nas relações diretas entre as partes à luz das normas da OMC.

Quanto às questões internas tem-se as variáveis: "legislação complexa", que associa a "burocracia interna", "lentidão do sistema" e "carga tributária", devem ser avaliadas e revistas internamente, de forma a agilizar os métodos de exportação e as tramitações inerentes ao processo. Todas elas estão de certa forma interligadas, uma vez que a legislação complexa é, por si só, causadora de lentidão em todo o sistema, que levam a burocracias exageradas, estas travam todo o sistema e tudo isso levando à elevação dos custos do processo, provocando a necessidade de aumento de impostos afim de cobrir tais custos

Já no que se refere às questões externas elencadas pelo programa utilizado tem-se, "barreiras tarifárias", "barreiras sanitárias", barreiras técnicas", "cotas" e "legislações específicas", estas questões deverão ser tratadas na esfera das relações internacionais, em sistema de ganha-ganha, estas trocas são comuns nestas relações entre as partes, uma vez que sempre existem interesses mútuos a serem atendidos levando a ajustes que atendam a todas as necessidades. Quando estes acordos não são suficientes para o equilíbrio dos referidos interesses e existem irregularidades nas exigências envolvidas, então a OMC deverá ser acionada para dirimir as dúvidas existentes entre as partes.

Este programa, de fácil utilização e entendimento, quando bem alimentado, com dados bem selecionados, vindos de fontes seguras e fidedignas, apresentam um real panorama do que está ocorrendo dentro do contexto estudado e se torna fonte de análise importante para a busca dos caminhos a serem escolhidos no direcionamento dos negócios e planos de futuro.

A análise da prospectiva estratégica depende de dados muito sólidos e confiáveis quando da alimentação do sistema, deve-se ter grande critério quanto da escolha dos especialistas envolvidos no sistema. Cada informação incluída no programa é analisada e cruzada com as demais, afim de buscar o seu grau de interação e sua força dentro de contexto, o programa simplesmente interpreta os dados ali incluídos, por isso o critério de pesquisa e recolha dos dados é de fundamental importância, e cada informação incluída deve ser avaliada e analisada para que realmente seja um dado importante para o programa, não distorcendo sua análise.

O sistema MICMAC, apesar de ser uma ferramenta de análise de dados, não é capaz de descartar dados irrelevantes, ou perceber que este ou aquele não se enquadra bem no contexto a ser analisado, por isso o critério de escolha deve ser 
criterioso, ele é que trará sustentação para o modelo e faz com que os resultados sejam confiáveis e possam servir de parâmetro para a tomada de decisão.

\section{CONSIDERAÇÕES FINAIS}

O mercado internacional se mostra extremamente dinâmico e sua análise nunca atingirá a plenitude do conhecimento necessário às tomadas de decisões mais acertadas na busca dos melhores resultados de mercado, por isso os estudos e avaliações devem ser constantes e continuados. As ferramentas aqui apresentadas são apenas algumas das tantas disponíveis para a análise deste complexo mercado, que envolve tantas variáveis, diferentes culturas, religiões e línguas, nada se esgota dentro desta análise, tudo é apenas um pequeno arranhão nesta grossa crosta, que envolve este complexo universo de possibilidades.

Desta forma muitas outras ferramentas podem ser utilizadas, para levantamento de dados, que possibilitam uma análise ainda mais profunda dos entrevistados, afim de explorar ao máximo as possibilidades e se recolher ainda mais variáveis de senso comum entre os especialistas.

\section{REFERÊNCIAS}

ABPA - Associação Brasileira de Proteína Animal. Publicações. Disponível em: http://abpa-br.com.br/. Acesso em 15/12/2015.

Relatório Anual 2017. Disponível em http://abpabr.com.br/setores/avicultura/publicacoes/relatorios-anuais/2017. Acesso em 18/01/2017.

AGÊNCIA BRASIL. Líder mundial, Brasil vende carne de frango para 150 países. Disponível em: http://agenciabrasil.ebc.com.br/economia/noticia/2015-09/lidermundial-brasil-vende-carne-de-frango-para-150-paises.

Acesso em 20/01/2016.

AVISITE - O Portal da Avicultura. Cai a competitividade do frango brasileiro. Disponível em http://www.avisite.com.br/clipping/imprimir.php?codclipping=21622. Acesso em dez/2015.

Os 25 principais importadores da carne de frango brasileira em 2016. Disponível em http://www.avisite.com.br/noticias/imprimir.php?codnoticia=17624. Acesso em 18/01/2018.

BRASIL. Rastreabilidade e segurança alimentar. Boletim técnico, n. 91, p. 1-25. Universidade Federal de Lavras, Lavras: UFL, 2012.

Novos mercados e a alta do dólar puxam ganhos dos exportadores de carne de frango. Seção Economia e Emprego. 11/09/2015. Disponível em http://www.brasil.gov.br/economia-e-emprego/2015/09/novos-mercados-e-alta-dodolar-puxam-ganhos-dos-exportadores-de-carne-e-frango.

Acesso em 12/01/2016. 
CEPEA - Centro de Estudos Avançados em Economia Aplicada - Esalq/USP. Frango/CEPEA. Setor avícola em 2015 e perspectivas para 2016. Disponível em: http://cepea.esalq.usp.br/frango/custos/2015/03Set_Dez.pdf.

Acesso em 19/01/2016.

CODEX ALIMENTARIUS. 2012. Disponível em: < http://www.codexalimentarius.org/>. Acessado em 13/01/2016.

DIAS, A. R. Barreiras não tarifárias as exportações de carne bovina no Rio Grande do Sul sob a ótica do sistema integrado agroindustrial (SIAN). $215 \mathrm{f}$. Dissertação (Mestrado em Agronegócios) - Universidade Federal do Rio Grande do Sul, Porto Alegre, 2003.

EBC - Empresa Brasil de Comunicação. Líder mundial, Brasil vende carne de frango para 150 países. 2015. Disponível em: http://www.ebc.com.br/noticias/economia/2015/09/lider-mundial-brasil-vende-carnede-frango-para-150-paises.

Acesso em 18/12/2015.

FARIA, R. N. de. Avaliação dos efeitos das exigências técnicas nas exportações brasileira de alimentos. $170 \mathrm{f}$. Tese (Doutorado em Ciências) - Escola Superior de Agricultura "Luiz de Queiroz", Universidade de São Paulo, Piracicaba, 2009.

FRANÇA, J. M. Barreiras técnicas e desempenho da cadeia produtiva de frangos no estado do Paraná. 130f. Tese (Doutorado em Engenharia de Produção e Sistemas) - Programa de Pós-Graduação em Engenharia de Produção, Universidade Federal de Santa Catarina, 2006.

G1.Apesar da carne Fraca, exportação de carnes brasileiras sobe $\mathbf{9 \%}$ em março. Seção Economia. Disponível em https://g1.globo.com/economia/noticia/balancacomercial-registra-superavit-recorde-em-marco.ghtml. Acesso em 18/01/2018

GODET, M. From Antecipation to Action. A handbook of Strategic Prospective. United Nations, UNESCO, Paris, França. 277p. 1993.

2011.

A prospectiva estratégica: para as empresas e os territórios, UNESCO,

GONÇALVES, J. S.; PEREZ, L. H. Exportações brasileiras da cadeia de produção de aves no período 2000-2005: origem, destino e agregação de valor. Informações Econômicas, v. 36, n. 7, p. 32-47, 2006.

IEA - Instituto de Economia Agrícola. Brasil, OMC e o Comércio Desleal. Análises e Indicadores do Agronegócio. v.4, n.9, setembro/2009. Disponível em: http://www.iea.sp.gov.br/ftpiea/AIA/AIA-36-2009.pdf.

Acesso em 09/01/2016. 
LIPSOR. MICMAC - Software Version 6.1.2 2003/2004, Matrice d'Impacts Croisés Multiplication Appliqués à un Classement. Disponível em http://www.3ie.org/lipsor/ download/formulaire_uk.php França. 2004.

MAPA - MINISTÉRIO DA AGRICULTURA, PECUÁRIA E ABASTECIMENTO. Brasil e Rússia vão intensificar comércio com prelisting de produtos de origem animal. Disponível em:

http://www.agricultura.gov.br/comunicacao/noticias/2015/07/brasil-e-russia-vaointensificar-comercio-com-prelisting-de-produtos-de-origem-animal. Acesso em: 18/01/2016.

MARCIAL. C., GRUMBACH, R. J. S. Cenários Prospectivos. Como Construir um Futuro Melhor. Editora FGV. Rio de Janeiro, Brasil. 148p. 2004.

MDIC/SECEX - MINISTÉRIO DO DESENVOLVIMENTO INDÚSTRIA E COMÉRCIO EXTERIOR/SECRETARIA DE COMÉRCIO EXTERIOR. Barreiras externas às exportações brasileiras. Disponível em: <http://www.desenvolvimento.gov.br>. Acesso em: 12/01/2016.

Barreiras Técnicas ao Comércio. Disponível em:

http://www.desenvolvimento.gov.br//sitio/interna/interna.php?area=5\&menu=733. Acesso em: 08/01/20016.

PAULA, S. R. L.; FAVERET FILHO, P. S. C. Exportações de carne de frango. BNDES Setorial, Rio de Janeiro, n. 17, p. 93-108, 2007.

SECEX - Secretaria de Comércio Exterior. Publicações. Disponível em: www.desenvolvimento.gov.br.

Acessado em 03/01/2016.

SILVEIRA, L. M. Entendendo a OMC e seu sistema de solução de controvérsias. Disponível em: http://internacionaleconomico.blogspot.com.br/2011 /07/entendendo-omc-e-solucao-dos-conflitos.html.

Acessado em: 04/01/2016.

TURRA, F. Avicultura: competitividade em jogo. Jornal Gazeta do Povo. Disponível em http://www.gazetadopovo.com.br/opiniao/artigos/avicultura-competitividade-emjogo-3t3e697wh57naj1ysxryqrxam. Acesso em 18/01/2018.

VERGARA, F. H.; NETTO, O. M. C. Análise estrutural por meio da metodologia MicMac aplicada à gestão dos recursos hídricos - 0 caso da região Hidrográfica da UHE Lajeado na bacia do rio Tocantins, Brasil. REGA - Vol. 4, no. 2, p. 5-20, jul./dez. 2007.

VILANCULOS, A.J.; NHASSENGO, O.; CAFÉ, M. B. A cadeia de valor da carne de frango no estado de goiás: uma visão atual e algumas reflexões comparativas sobre a produção de carne de frango em chibuto-Moçambique. Sociedade e Território, v. 27, n. 3, p. 79-94, 2015. 